\title{
Dispersão de Material Impactante em meio Aquático: Modelagem Matemática e Aproximação Numérica - Lago Perucaba, Arapiraca-AL
}

\author{
Fernando Vieira Costa Júnior \\ Rodrigo Costa \\ Sebastião Bruno Melo Paz \\ Universidade Federal de Alagoas, UFAL \\ E-mail: nanndo_00@hotmail.com rodrigo_costa_al@ hotmail.com, sebastiao.paz@arapiraca.ufal.br
} Rinaldo Vieira da S. Júnior

Universidade Federal de Alagoas, UFAL

57309-005, Campus Arapiraca, Arapiraca, AL rinaldo.junior@arapiraca.ufal.br

\section{RESUMO}

Como em várias cidades do Brasil em rápido desenvolvimento, a cidade de Arapiraca localizada no estado de Alagoas sofre com problemas advindos do crescimento populacional, tal como a ocupação desordenada das áreas urbanas que vem agravando ainda mais o saneamento básico, como por exemplo, o lançamento de resíduos sólidos através de esgotos domésticos das casas ribeirinhas e das casas mais próximas ao corpo hídrico como também as águas de drenagem urbana [3]. Entre os anos de 1970 e 2000, a cidade tem apresentado alto crescimento da taxa populacional, com um aumento de 97, $76 \%$. Com o aumento da população urbana, surgiram diversos problemas associados, entre eles a falta de saneamento básico [1]. Este problema decorre da falta de planejamento e regulamentação da ocupação destas áreas, aliado ao uso inadequado do solo nesses ambientes [4, 9, 3].

O Lago Perucaba, antigo açude do DNOCS-Departamento Nacional de Obras Contra a Seca, foi construído na década de 60 com o objetivo de abastecer a cidade por meio do represamento do Rio Perucaba, o qual não foi alcançado devido ao alto teor de sal nas águas represadas além de ser considerado um dos principais contribuintes da elevação da concentração de carga orgânica no Baixo São Francisco [2]. Este manancial, que se encontra numa área de Proteção Permanente-APP,- compõe a Região Hidrográfica do rio Piauí, juntamente com as bacias hidrográficas do próprio rio Perucaba (com área de drenagem de $\left.637,7 \mathrm{~km}^{2}\right)$, rio Tibiri $\left(129,5 \mathrm{~km}^{2}\right)$, rio Itiúba $\left(469,6 \mathrm{~km}^{2}\right)$, rio Boacica $\left(808,8 \mathrm{~km}^{2}\right)$, rio Piauí $\left(1109,4 \mathrm{~km}^{2}\right)$, rio Batinga $\left(159,3 \mathrm{~km}^{2}\right)$ [10].

Recentemente, surgiram algumas ações no sentido de revitalizar a área do entorno do Lago, com objetivo de transformá-lo em local de prática balneária para população local [9]. Estudos realizados através de parceria público-privada que avaliam a qualidade da água no Lago, serviram de base para definir a sua balnealidade através da Resolução ${ }^{\circ} 274$ do Conselho Nacional do Meio Ambiente-CONAMA e indicaram que o mesmo encontra-se contaminado [9].

Através de análises bacteriológicas e físico-químicas realizadas pela Companhia de Saneamento de Alagoas-CASAL ficou evidente que não foram cumpridos ações importantes direcionadas para cuidados com relação a emissão de resíduos líquidos, sólidos e na urbanização do entorno do Lago Perucaba.

Pretendemos neste estudo determinar o potencial de degradação de matéria orgânica na água. Para tal finalidade, faremos uso do modelo clássico de equações de difusão-transporte-reação da concentração de um poluente, onde $C(x, y, t)$ denota a concentração de um poluente e num ponto $(x, y) \in \mathbb{R}^{2}$, este problema pode ser modelado na forma

$$
\frac{\partial C}{\partial t}=\operatorname{div}(\alpha \nabla C)+\operatorname{div}(\mathbf{V} \cdot C)-\sigma C+f
$$

onde $\alpha$ é a constante de difusibilidade do poluente, $\mathbf{V}$ é o campo de velocidades e $\sigma$ é o decaimento do poluente, [11]. 
No desenvolvimento dos estágios da modelagem matemática proposta, pretendemos utilizar equações diferenciais ordinárias para determinar a concentração de poluentes orgânicos no lago, utilizando equações de diferenças finitas para discretização do modelo e simulação computacional, como também considerações sobre os parâmetros do modelo [7, 11, 8]. A modelagem matemática proposta num determinado problema real pode oferecer uma previsão significativa, indicando prioridades nas aplicações de recursos pelos órgãos competentes [5].

Como estudo preliminar, ainda não dispomos de dados previamente estipulados no Lago, isto será incorporado na modelagem durante a pesquisa $[5,6]$. Pretendemos descrever a evolução de material impactante no Lago, causado pelo lançamento de efluentes líquidos (domésticos e esgoto) e sólidos (industrial) provenientes da ação humana.

Este estudo já aponta uma primeira estimativa do decréscimo da qualidade da água no Lago e seu impacto ambiental no meio ambiente ao redor, bem como a população que se utiliza dos ambientes próximos ao lago para residir, além do lazer e desta forma estando em contato direto com água contaminada do Lago. Assim, esperamos com este estudo preliminar oferecer um suporte para futuras ações governamentais com o objetivo de direcionar ações de prevenção e monitoramento, em busca da solução problema em questão garantindo uma maior segurança para população local.

Palavras-chave: Modelagem Matemática; Impacto Ambiental; Método das Diferenças Finitas; Biomatemática .

\section{Referências}

[1] ARGEMIRO, F. S. da “Impacto do saneamento “ in situ” nas Águas da Bacia hidrográfica do riacho Piauí: Perímetro Urbano do Município de Arapiraca-AL”, Monografia (Licenciatura em Geografia), Arapiraca-AL, FUNESA/FFPA, 2005.

[2] BRASIL. Ministério do Meio-Ambiente. Superitendência de Planeamento de Recursos Hídricos Agência Nacional de Águas (ANA). Cadernos de recursos hídricos 1. Panorama da qualidade das águas superficiais no Brasil. Brasília: TDA Desenho \& Arte Ltda, 172 p., 2005.

[3] RAMOS, E. de A., " Percepção ambiental da população da cidade de Arapiraca em relação ao Açude DNOCS ”, 62 p., Monografia (Licenciatura em Geografia), Arapiraca, FUNESA/FFPA, 2006.

[4] CARVAlHO, F. S; HERnANDEZ, A. de O; CARVAlHO, G. S. “ Estudos Hidrológicos de cheias da bacia da Perucaba com ênfase a cota de inundação do Lago da Perucaba, zona urbana da cidade de Arapiraca-AL”, In: XIX Simpósio Brasileiro de Recursos Hídricos, Maceió-AL, 2011.

[5] BASSANEZI, R. C. " Ensino-aprendizagem com modelagem matemática”, 3 ed., São Paulo, Editora Contexto, 2011.

[6] BATSCHELET, E. “ Introduction to mathematics for life scientists”, Editora Springer, 1979.

[7] CUNHA, M. C. C. “ Métodos Numéricos ”, 2 ed., Editora Unicamp, 2000.

[8] SEBUSKE, A.O. et al. " Poluição em recursos hídricos por matéria orgânica: modelagem matemática e determinação de parâmetros”, In: CMAC Sudeste 2013, pp. 309-310, Bauru-SP, 2013.

[9] BRITO, A. S. de; XAVIER, R. A. "Avaliação da qualidade de água do Lago da Perucaba em Arapiraca-AL para a prática da balneabilidade ", In: SIMAGA, 1o., 2010, pp. 31-42, Arapiraca-AL.

[10] HYDROS, "Plano Diretor de Recursos Hídricos da Bacia do Rio Piauî́, SEMARH-AL, 1998.

[11] POLETTI, E. C. C; MEYER, J. F. C. A. "Dispersão de Poluentes em um sistema reservatório: Modelagem matemática via lógica Fuzzy e aproximação numérica", Biomatemática, 19, pp. 57-68, 2009. 